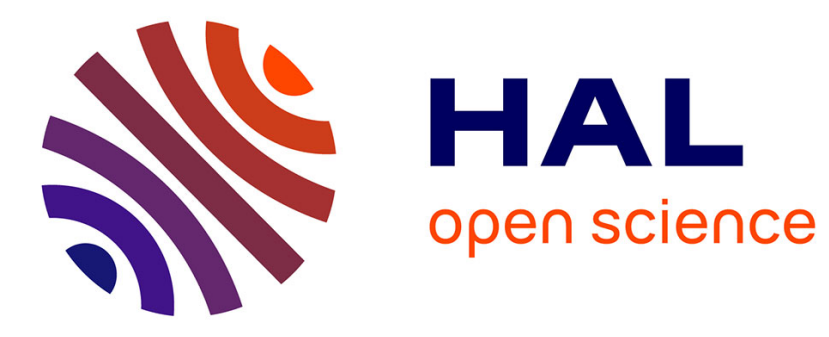

\title{
Heterogeneity of histaminergic neurons in the tuberomammillary nucleus of the rat
}

Patrizia Giannoni, Maria-Beatrice Passani, Daniele Nosi, Paul L Chazot, Fiona C Shenton, Andrew Medhurst, Leonardo Munari, Patrizio Blandina

\section{- To cite this version:}

Patrizia Giannoni, Maria-Beatrice Passani, Daniele Nosi, Paul L Chazot, Fiona C Shenton, et al.. Heterogeneity of histaminergic neurons in the tuberomammillary nucleus of the rat. European Journal of Neuroscience, 2009. hal-01756945

\section{HAL Id: hal-01756945 https://hal.science/hal-01756945}

Submitted on 3 Apr 2018

HAL is a multi-disciplinary open access archive for the deposit and dissemination of scientific research documents, whether they are published or not. The documents may come from teaching and research institutions in France or abroad, or from public or private research centers.
L'archive ouverte pluridisciplinaire HAL, est destinée au dépôt et à la diffusion de documents scientifiques de niveau recherche, publiés ou non, émanant des établissements d'enseignement et de recherche français ou étrangers, des laboratoires publics ou privés. 


\title{
Heterogeneity of histaminergic neurons in the tuberomammillary nucleus of the rat
}

\author{
Patrizia Giannoni, ${ }^{1, *,+}$ Maria-Beatrice Passani, ${ }^{1,+}$ Daniele Nosi, ${ }^{2}$ Paul L. Chazot, ${ }^{3}$ Fiona C. Shenton, ${ }^{3}$ \\ Andrew D. Medhurst, ${ }^{4}$ Leonardo Munari ${ }^{1}$ and Patrizio Blandina ${ }^{1}$ \\ 'Dipartimento di Farmacologia Preclinica e Clinica, V.le G. Pieraccini 6, Universitá di Firenze, 50139 Firenze, Italy \\ ${ }^{2}$ Dipartimento di Anatomia, Istologia e Medicina Legale, Viale Morgagni, Universitá di Firenze, Firenze, Italy \\ ${ }^{3}$ Centre for Integrative Neuroscience, School of Biological and Biomedical Sciences, Science Park, Durham University, Durham, UK \\ ${ }^{4}$ Neurosciences Centre of Excellence for Drug Discovery, GlaxoSmithKline, New Frontiers Science Park, Harlow, Essex, UK
}

Keywords: $\mathrm{GABA}_{\mathrm{A}}$-receptor, $\mathrm{H}_{3}$-receptor, microdialysis, wakefulness

\begin{abstract}
Histaminergic neurons of the hypothalamic tuberomammillary nuclei (TMN) send projections to the whole brain. Early anatomical studies described histaminergic neurons as a homogeneous cell group, but recent evidence indicates that histaminergic neurons are heterogeneous and organized into distinct circuits. We addressed this issue using the double-probe microdialysis in freely moving rats to investigate if two compounds acting directly onto histaminergic neurons to augment cell firing [thioperamide and bicuculline, histamine $\mathrm{H}_{3^{-}}$and $\gamma$-aminobutyric acid $(\mathrm{GABA})_{A^{-}}$-receptor $(\mathrm{R})$ antagonists, respectively] may discriminate groups of histaminergic neurons impinging on different brain regions. Intra-hypothalamic perfusion of either drug increased histamine release from the TMN and cortex, but not from the striatum. Thioperamide, but not bicuculline, increased histamine release from the nucleus basalis magnocellularis (NBM), bicuculline but not thioperamide increased histamine release from the nucleus accumbens (NAcc). Intra-hypothalamic perfusion with thioperamide increased the time spent in wakefulness. To explore the local effects of $\mathrm{H}_{3}-\mathrm{R}$ blockade in the histaminergic projection areas, each rat was implanted with a single probe to simultaneously administer thioperamide and monitor local changes in histamine release. Thioperamide increased histamine release from the NBM and cortex significantly, but not from the NAcc or striatum. The presence of $\mathrm{H}_{3}$-Rs on histaminergic neurons was assessed using doubleimmunofluorescence with anti-histidine decarboxylase antibodies to identify histaminergic cells and anti- $\mathrm{H}_{3}-\mathrm{R}$ antibodies. Confocal analysis revealed that all histaminergic somata were immunopositive for the $\mathrm{H}_{3}-\mathrm{R}$. This is the first evidence that histaminergic neurons are organized into functionally distinct circuits that influence different brain regions, and display selective control mechanisms.
\end{abstract}

\section{Introduction}

Somata of aminergic neurons are restricted to discrete cell clusters in distinct brain regions, although their axons innervate nearly the entire CNS. Locus coeruleus, substantia nigra and dorsal raphe are sources of noradrenergic, dopaminergic and serotonergic axons, respectively. These nuclei are comprised of distinct compartments with respect to projection fields, as separate subgroups of noradrenergic $(\mathrm{A} 1-\mathrm{A} 7)$, dopaminergic ( $\mathrm{A} 8 \mathrm{-A17})$ and serotonergic (BI-B9) neurons give rise to distinct sets of axons innervating separate brain regions (Mason \& Fibiger, 1979; Jacobs \& Azmitia, 1992). This pattern implies independent functions of sets of neurons according to their origin and terminal projections.

Correspondence: Dr P. Blandina, as above.

E-mail: patrizio.blandina $(a$ unifi.i

*Present address: Department of Pathology, New York University School of Medicine, New York, NY 10016, USA.

${ }^{\dagger}$ P.G, and M.B.P. contributed equally to this article.
In a comparable architecture, all fibres containing histamine, another aminergic neurotransmitter (Schwartz, 1975), originate within the hypothalamic tuberomammillary nuclei (TMN; Panula et al., 1984; Watanabe et al., 1984), and innervate almost the entire CNS (Inagaki et al., 1988; Panula et al., 1989a; Brown et al., 2001). Histaminergic neurons are grouped in five clusters, El-E5 (Inagaki et al., 1988), each of which sends overlapping projections throughout the neuroaxis (Ericson et al., 1987). Retrograde tracers injected into different CNS regions labelled histaminergic cell bodies scattered throughout the TMN without a strict topographical pattern (Kohler et al., 1985; Inagaki et al., 1990). Thus, histaminergic neurons appear as a rather homogeneous cell group acting as a regulatory network for wholebrain activity through diffuse projections, and modulating general states of metabolism and consciousness, rather than processing specific functions (Wada et al., 1991). Evidence is beginning to accumulate showing the heterogeneity of histaminergic neurons. Different types of stress (Miklos \& Kovacs, 2003) and hypercapnic loading (Haxhiu et al., 200I) activated subgroups of histaminergic neurons. Histamine neurons differ in size, glycine-sensitivity (Serge- 


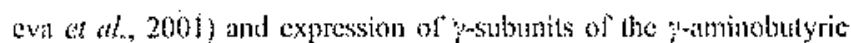

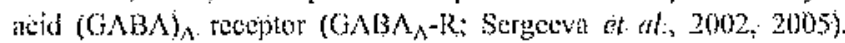
'These observations stugiges that the histumergie system is organized into distinct circhits. Lach triggering specilic physiological responses. including atrousal; appetite and cognitive processer (Tlas \& Panuli, 2003; Passui ct al. 2004; litas et al. 2008).

The $\mathrm{H}_{3}$-receptar $\left(\mathrm{H}_{3}-\mathrm{R}\right)$ is in ato-and a hetero-receptor, controt ling release of histamine itself as well as a range of other neliofransmitters (Arrang at al. 1983: Biandina ef at. 1998). It shows lunclonal constititive activity: polynorphisms in humars and rodenfs will a diflereytal distribution of splice variants, and coupling to different intracellukar signal transduction mechanisms (laassani of al, 2004). $\quad \mathrm{l}_{3}=\mathrm{K}$ helerogeneity might underlic the diversity of histaninergic neuronal functions. To understand if bistaminerigic netrons are organized into distinct functiongl circuits, we used the

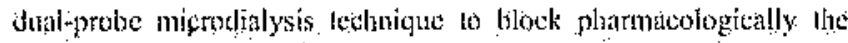
$H_{3}, R$ or the $G A B A_{A}-R$ in the TMN and monitor modification of histamine reletse in listaminergic projection areas Single-probe microdialysis experinents were also perlomed to investigate whelter blockade of local $I_{3}+\mathrm{R} s$ in the listaminergic projection areas influched histandine release within these brain regions. In this stendy; we demonstrate that histaminergic neurons are characterized by independent control nuechanisms and differential oilput to specific brain regions: This arraigchent ma inflietice isdividually defitied behavions restiting from differential histamine relense in various btain regions.

\section{Materials and methods}

Light-week old, male Sprague-1)awley rals (250 280 g body weight; Harlan, haly) were housed in groups of lloree in a temperatureconirolled room $\left(20 \% 24^{\circ} \mathrm{C}\right)$, of a 12 h lighl : dark eycle $(07,00$. $19.00 \mathrm{~h})$ and were allowed lree access to bool and water. Alt the experiments were pertorned in strict complance with the BLC recommendations for the eare and tase of laboratory animals (86/609/Cl:E), and were approved by the Animal Care Commitce of the "Dipartimento de Farmacologia Preclinica e Clinica -.. Universita di Firenze".

\section{Surgical procedures}

Rats, anaesthelized with chloral hydrate $(400 \mathrm{mg} / \mathrm{kg}$ i.p. $)$ and positioned in a slercolaxic frame (Stelfar, Stecliting, Wood Dale, IL, USA), were implanted with gutde cantulae (Metalant, Sweden) according to the foltowing coordinates tron bregmil (Paxinos \& Walson, 1998): TMN, $A \mathrm{p}=-43, \mathrm{~L}=-1.1, \mathrm{DV}=-7.2$; nicleus

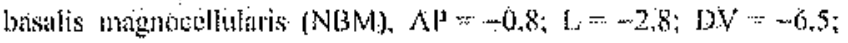

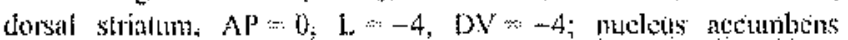
(NAcc), $A P=2.2, L=-1,4, D V=-6,3$, pretrontal corlex, $\Delta \mathrm{P}-3,2: L,-1,0 ; \mathrm{DV}=-2.8$ (Fig. 1). $A$ surgical screw served as an anclior and the cannulue ware fixed to the skull with acrylic deital centicnt. In the donl-probe experinents. one probe wats plated in the TMN of erery rat, will a second probe in one of thor locations (NBM, dorsal striatum, NAce or prefontal cortex) in the silgle-probe experitivents each ral was itriplantect witli a single probe in the NBM, dorsal strialım, NAece or preftonial curtex.

\section{In vivo microdialysis measurements of histamine}

The microditysts experiments were performed 48 h after surgery, during which rats, hotsed one per eage, recovered from surgery. Rats were handled for at least 4 days befort experiments began, thes becouning acelimatized to human contach the stylet was rejnoved from the gude ctintilac, and the microdialysis probes fondectar weight eutan :-6000 Da, Metalam Sweden were inserted; the dialysing membrane protruded 2 min from the tip of the anmula. Probes were perfused will Ringer's solttion (in ma: NaCl, 147\%

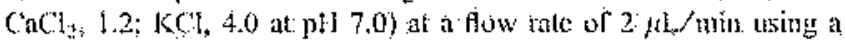
microperfusion pump (Cannegie. Medicine, Sweden: Mod CMA 100). Histanine release stabilized 2 hatter insertion of the nictodialysis probes. Alter litis 120-min equilibration period. Hactions were collected at 15 -nin intervils. In the dual-probe experinosts; both probes were perfused with conlrot mediun in the first four/five 15-min fractions to mensure fistamine spontancous reletse; thioperamide or bicuculitie were then added only to the TMN,perlising medim: Thioperatide or biciculline were disstelved into the Ringers solution to reacli final concentrations of $300 \mathrm{~nm}$ and 10 $\mathrm{fm}$, respectively, Drugs andition did nol modify the pll of the medum. In the single-probe experinents the brain region of interest was perfused will control medium in tic first five fractions; and Itioperande (300 11M) was then added to the perfusitg meditm. Histamine spontancous release was lefined as the arerage value of histanine levels in the fou/five 15-min fractions colfected oflring perlusion with Ringer's solution prior to drug tratinembl. All fraclions were exprissed as a percentage of this value. To preverit degradalion

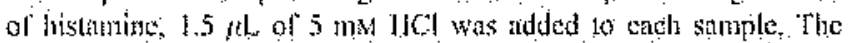
dialysates were kept at $-80^{\circ} \mathrm{C}$ until analysis. Drugs were applied in Ringer'sit solution.

\section{Microdialysis and behavioural coupled experiments}

To determine whelher the sleep/wake behaviour varicd will the increase in TMN histamine relense indued by local perfusion wilh thioperanude, we measured the wake time in a set of eight ratts implanted with a singte microdialysis probe in the TMN and perfused with a mediun containing thioperantide 300 nivi: Surgical procedures were the same as deseribed above. The collecilon of perfisate from the TMN started afler a 120-min equilibration period. The probe was perlused with control madium lor" a 60-min fraction to nieasure histanime spontaneous retense: thoperamite (300 ma) was then added to the perfustug medium for the following 60 min. Sinteltaneously, the belavís of each animal was visually monitored by experienced individuats, bjiad to the experimental protocti, and categorized as "slepp' or 'wake", according to Ko et al, (2003). Animals displaying a curled posture wilh a tucked head and lail and closed eyes were calegorized is 'slecp'. Conversely, at atrinal was eategorized ás 'Wake' if it aisplayed upright posture or eurled posture with open eyes, body movements such as grooning, stratching, cating, standing, snifing burrowing, adjusting tail or head position. stretching, "The wake time was tnetsured witl a stopwatch and reported on special Coms, Experintents begiti at $10.00 \mathrm{~h}$, sund exded by $12.00 \mathrm{~h}$. 10 limit the inflence of eireadian tactors. One rat was exchuded fiom analysis hecatse its lime spert in wakefilness doring the 60 min under basetine conditions was gricaler blon 2 standard deviations from the group mean.

\section{Determination of histamine concentration by high performance hquid chromatography (HPLC) fluorimetry}

thistanitio contents in the dialysales were determined by APLCfluorimetry nising a modified yersion (Cenni at at, 2006) of the protocot by Yamalodani et al. (1085). Briefly, the colum (Hypersil 

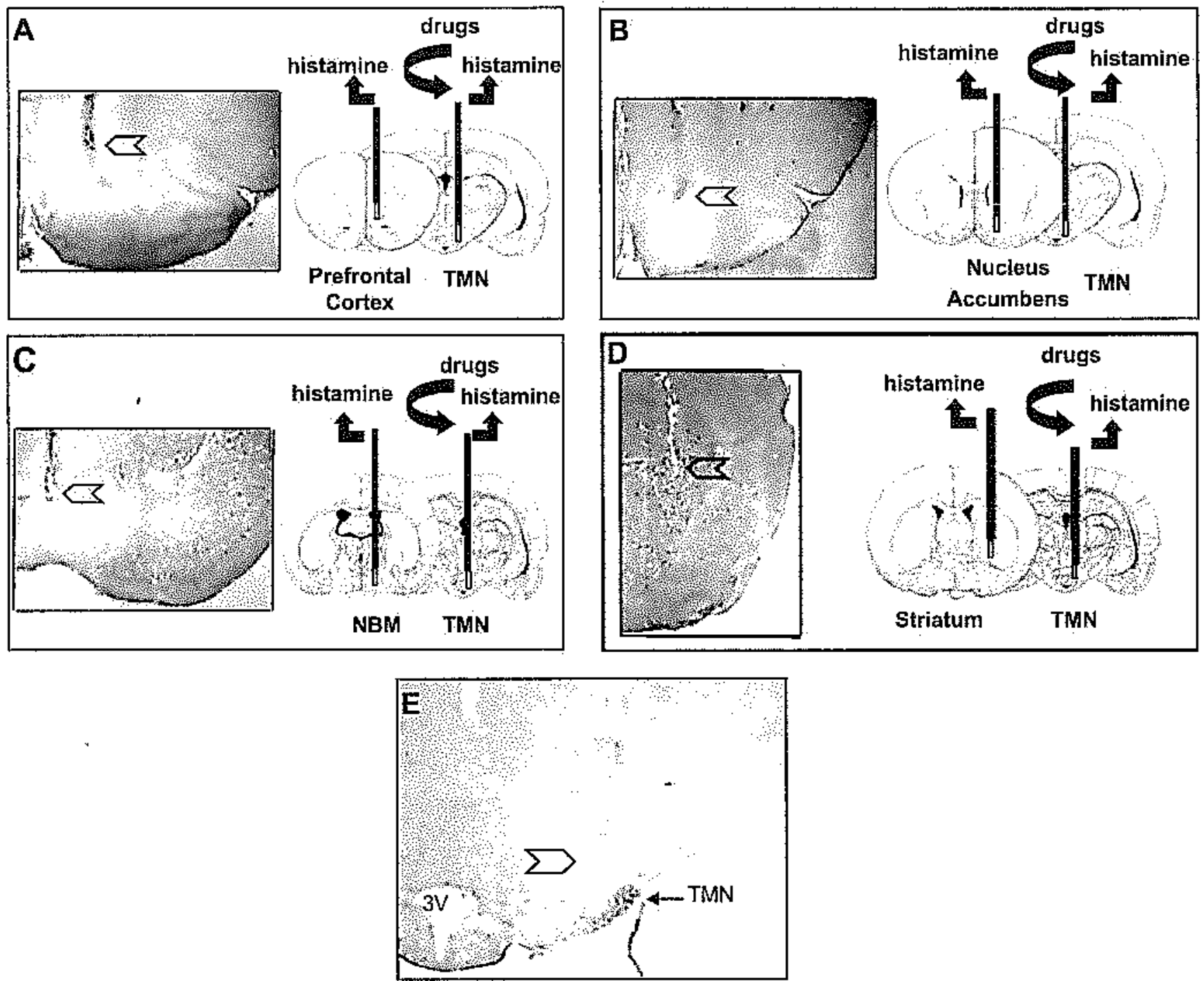

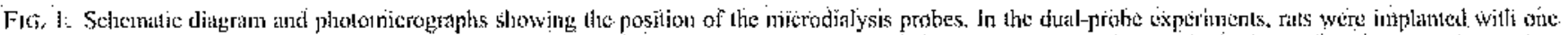

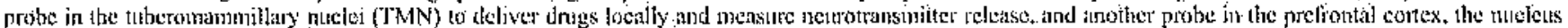

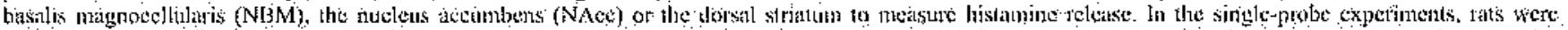

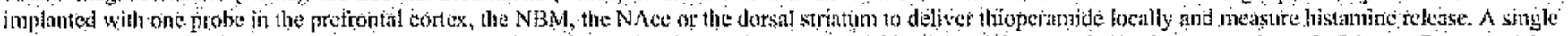

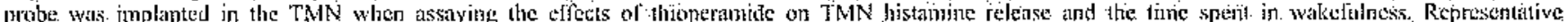

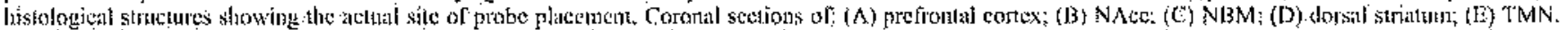

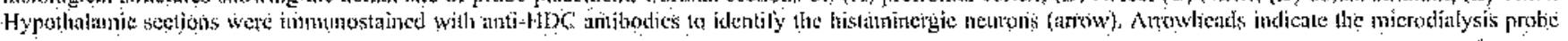
traces.

ODS, $3 \mu \mathrm{m}, 2: 1 \times 100 \mathrm{~mm}$; Thermo Electron, Bellefonie, PA; USA) was cluted with 0.25 is politssim diliydrogen plosphtate conlaining $5 \%$ octariesulphonic acid (Signa) at al flow rate of $0.4 \mathrm{~mL} /$ min. The cluate from the colum was mixed firsil will $0.1 \%$ ophthalaldelycte solition at a fiow nate of $0.1 \mathrm{~mL} / \mathrm{min}$ and then wilh a solution containing $4 \mathrm{M}$ sodium hydroxide and $0.2 \mathrm{M}$ boic acid (llow rate $0.137 \mathrm{~mL} / \mathrm{min}$ ) to adjest the reaction mixture to pil 12.5. The renclion took place at $45^{\circ} \mathrm{C}$. Then $17 \%$ orlophosphoric acid was added to the solution (flow rate $0.137 \mathrm{~mL} / \mathrm{min})$ to reach is firtal reaction mixtute al pli 3 , The fluorescent intensity was measured will a spectrofluorometer (Agilent series 1100; Waldbrom, Germany) at $450 \mathrm{~mm}$ with excitation at $360 \mathrm{~nm}$, The sensitivily limit was $0.010 \mathrm{pmol}$ and the signal/notse fatio was líghis lhan 3 .

\section{Histology}

The placement of mierodialysis membrancs was verified post niontem. Rats were overtosed with chloral hydrate, the beains removed aid stored in $10 \%$ fonmalin for 10 days. Forty-micrometie-thick sections were ben cul on a cryostal, mointed on getalin-coated slides änd llien slained will Cresyl violet for light mierostopio observation. Data fiom rats in which the membrames were not correctly positioned were discarded $(e \mathrm{i}(0 \%)$.

\section{Immunohistochemistry}

A specific set of three male Sprague-Dawley rats $(250) 280$ g boily. weiglit; Harlan, taly) was ancesthelized wihn chloral hydrate and 
perfused transcardially will $50 \mathrm{~mL}$ iceowld physiologicat saline Fillowed by $4 \%$ paratomatdende in 0.1 w phosphate butfer (PB), pll 7.4 Btains were then postfixed in 4 ay paraformaldehyde in $\mathrm{PB}$ lor $2 \mathrm{f}$ at $4^{\circ} \mathrm{C}$. Bratis were cryoprolected in $30 \%$ sterose in $\mathrm{PB}$, and 40 -gritllick sections were clil on a cryostal microtome and collected in PB. The location of the histaminergic cells with respect to the microdialysis probe was assessed by immentostaining hypothalamic sections with antibodies ngainst histdine decatboxylase (HDC), the bistaminesynthesizing enzyme. The sections were inculated will rabbil antiIIDC (1 : 1000, Acrit, Bad Nauleim, Germany) overmigh al 4 ? then incubited will biotinylated anti-rabbit IgG antibodies (1 : 400; vector) lollowed by horseradish peroxidase-coingugated avidin acord. ing to the Vectastain kit (Vector). Immunoreaclive producls were visualized by incubalion with 3; 3 mdiamibobenzidine.

For double-lnbetting experionents, all inmumostaining proedures. were performied on freefloating sectịns as previously described (Shenton of al. 2005), wilh modifications. Briefly, Hit $\mathrm{H}_{\mathrm{i}} \mathrm{R}$ antigenretricual was perloned in $50 \mathrm{~mm}$ sodium citute (p) 8.5 ) al room temperative for 30 min. bollowed by 30 min at $80^{\circ} \mathrm{C}$. Sections were washed in Tris-buflered saline (T.BS) contitibing $0,2 \%$ Triton X-100 before blocking in TBS containing $2 \%$ foetal call senum (FSS) and $0.2 \%$ Tween 20 for 60 min at room temperature. Sections were thon incubated in a cocktail of rabbit anti-l $\mathrm{l}_{5}-\mathrm{R}$ anibodies $(0.5 \mathrm{mg} / \mathrm{mL})$ and guilinea pig anli-HDC $(1: 1000)$ priniay antibodies in :TBS containing $1 \% \mathrm{FCS}$ bernight at $4^{\mathrm{C}} \mathrm{C}$ Rabbit polyclonal antibodies for $\mathrm{I}_{3}-\mathrm{R}$ are directed aganss residucs 349.358 or the human and rat $\mathrm{I}_{3}-\mathrm{R}$ (Charol et al., 2001: Cannon at al, 2007: Crandi et al., 2008).
I'reabsompion experiments were carried out previously. and deseribed in Chazol et al (2001). After thoromgl rinsing in THS, sections werc

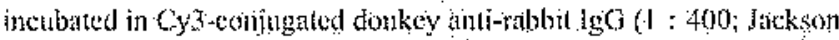
Immunoresearch, West Grove $\mathrm{PA}$, USA) in TBS containing la FCS for 90 min at room temperature. Aler extensive rinses in Tl3S, sections were incubated in Alexa fituor 488-jabelled, goal anli-guitiea

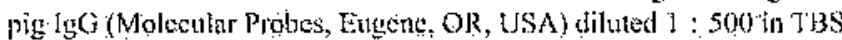
containing 10 t $\mathrm{CCS}$ for $90 \mathrm{~min}$ at roon temperature. Aler rinsing. sections were then moutaled on glass slides and coverslipped. Elimination of anti $+h_{3}+R$ primary antibodies resulted in no immunoștaining (nol shown). Conlocal antlysis was perforned with a Leien TCS SPS confocal scuming niicroseope (Leica Mannhim, Gernany), equipped willi a $\mathrm{HaNe} / \mathrm{Ar}$ laser and a Leich Plan Apo $\times 631.4$ oil inmersion objective. To avoid bleed-linrongfi, green (Alexa 488) and red (Cy3) fluoresetint sigmats were ilecilured sequentially, țsing the 488-nin and 543-nn texeitation laser line, respectively. Series of optical sections $(1024 \times 1024$ pixels, pixel sizc $204 \mathrm{~mm}$ ) were collected through the cells at intervals of $400 \mathrm{~mm}$ Confocal stacks were thein filtered with an F FT-busted bandpnss filter to cut backetound noise (structures down to $20 \mathrm{~m}$ and up to $204 \mathrm{~mm}$ ) and llsen zoprojected for vistatization.

\section{Statistical analysis}

All values are expressed as means $\Phi$ used in each experinent is also indieated. The presence of significant treatment eflecls was first detemined by an one-way ANovA followed

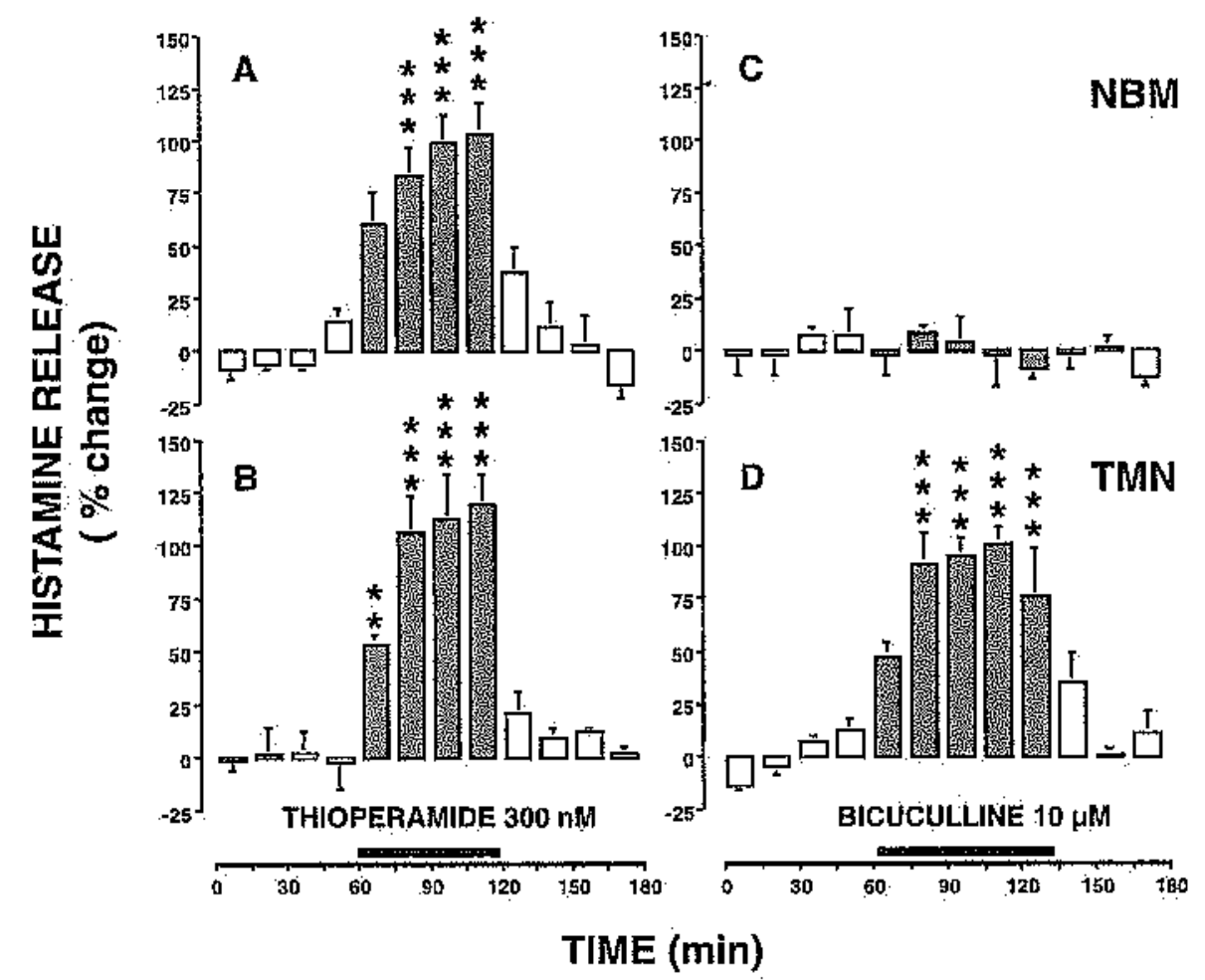

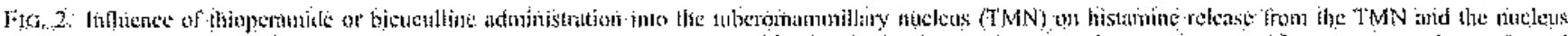

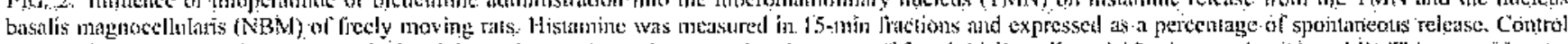

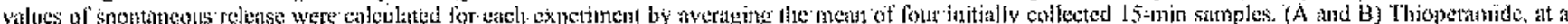

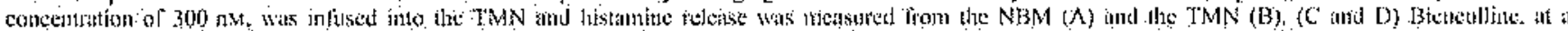

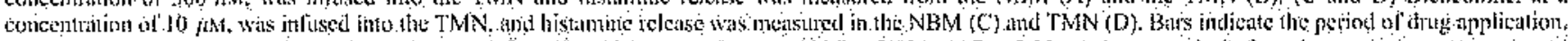

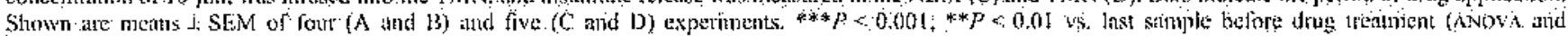
Bolferrani's icsis. 


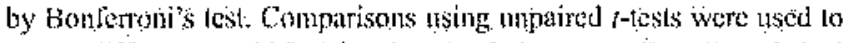
assecs differences within 'steep'. or 'wake' groups. For all statistical tesis, $p<0.05$ was considered significant. For clarity. we reported in figutes and figure legends anly the significatit differences from the last stimple before drug ireatment. However, differences were significant from all biseline samples. Statislical analysis was performed using STATVIEW (Abacus Coneepts: BerkIey, CA, USA)

\section{Chemicals.}

Bicueulline methiodide and tjioperamide malcale were purchased from . Signa (UK). Ail other reagenis and solvents were of HPLC: grade or the bightest grade available (Sigma, UK).

\section{Results}

After 120 min of equitibration following the insertion of the dialysing menbraines, bistanine was released spontancously at a stable rate from all brain regions investigated. Afler this 120-min equilibration period, liractions were coltected at $15-\mathrm{min}$ iniervals. Histological analysis confoned that the probes were located in the conect areas, will no siguss of unustual tissue damage or blecting (Fig. 1).

\section{Effects of local perfusion of thioperamide or bicuculline into the TMN on histamine release from the TMN and NBM}

After collection of four, 1.5 -min baseline samples, ilhoperamide or bicuculine were infused locally into the TMN, and hiskanine retease was monitored from boht ine TMN and NBM using a double probe microdialysis protocol, $A$ s shown in lig. $2 A$ and $B, 60$-min perfusion with 300 na thoperamide induced a signffieant increase in histamine rclcase from bolth (he NBM (ANONA, $\left.F_{11,3,}=10.861, p<0.0001\right)$ and the tMN (ANOVA, $F$ 11,36- 18.574, $P<0.0001$ ). Thioperamide at $300 \mathrm{~nm}$ is a selective antagonist/inverse agonist of the $\left[\mathrm{i}_{3} \mathrm{~K}\right.$ (Arrang ef al. 1987; Morissel et al, 2000). In the TMN the maximal

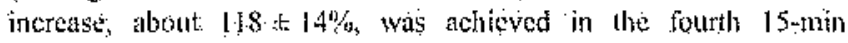
fraction collected after onsel of llue TMN perrusion with thioperamide, and hislamine release was restored to control levels during subsecuent TMN perfusion with control medium. llislamine spontanëous release fron TMN alveraged 0.037 : 0.064 pmol/15 miil (i) 4). All lyistamiiergic neurons are loctlized in the TMN and, supposedly, histamine is released by stiort projections in the posterior lypollatanus, where hislaminergic netrons have extensive axonal arborizalious (liagaki et al; 1988; l'anuta ot al, 1989a). Ilistimite releatse also increased in the $\mathrm{NBM}$, when thioperamide was infused inlo the TSMN, and it reached a maximitil level of approximately 103 at 15\%. Histamine oulput lended to remain elevaled lor the dutation of ilrioperanide application to the TMN, and then returned slowly to baselitue values after TMN perfusion with thiopcramide was complete. Histamine sponianeous reterse from NBM aviraged 0.041 t $0.005 \mathrm{pmol} / 15$ min $(0)=4$ ) A significant increase ol lisiamine release from the TMN was alsu observed during local perfision

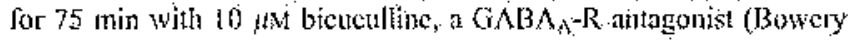
el at. 1984; ANOVA, $F_{11.48}=15.778, P<0,0001$; Fig. 2D). The maximal increase was $102 \pm 8 \%(n=5)$. Conversely, in the NBM, histamine spontancous relcasce was not nodified by TMN perfusion with bieuculline (Fig. 2C), The mean spontaneous release in this sel

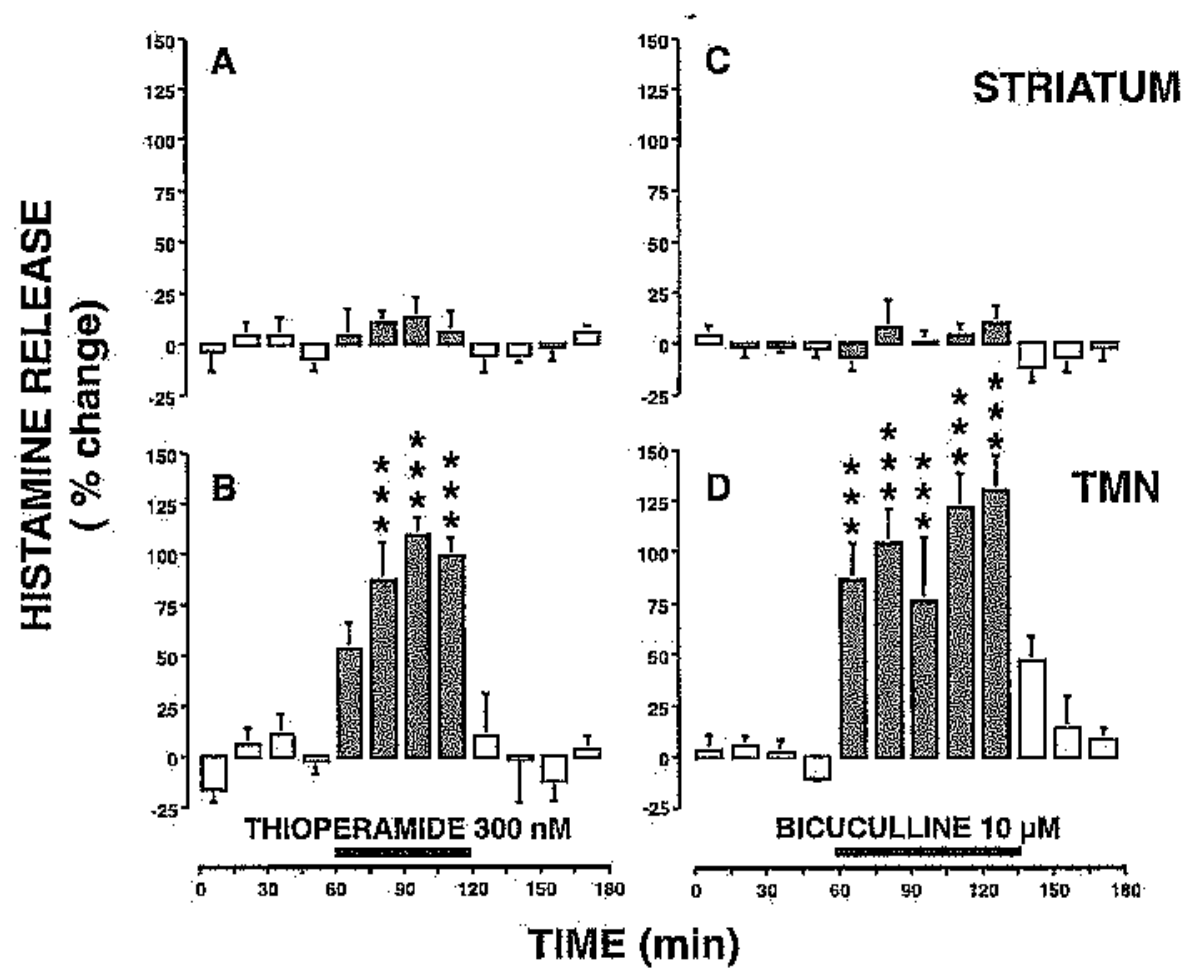

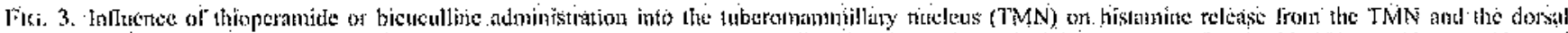

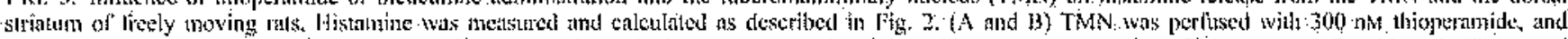

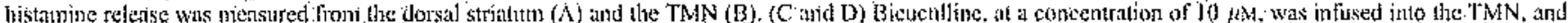

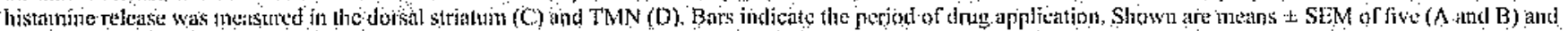

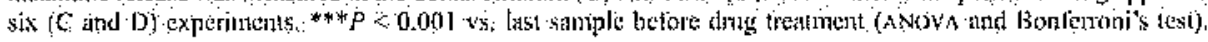


of experiments was 0.100 t 0.008 pmol 15 min in the TMN, and

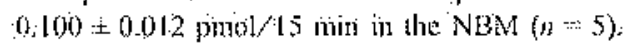

Perfusion of thioperamide or bicuculine into the TMN did not. modify spontaneous release of histamine from the dorsal striatum

Pertision of the TMN with eilluer 300 nu thioperamide (Fig. 3B) or

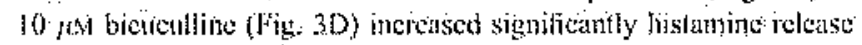

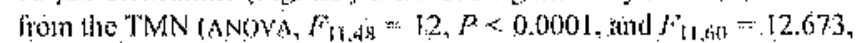
$P<0.0001$, respectively), wilh comparale mag! itude and time course to sfudies shown th lig. 2. Thioperamide inereased histamine releose significanily ip to $109 \pm 0 \%$, itsd bicuculline up to $130 \pm 17 \%$ of respective basal levels. The treair listamine spontaneous release from the TMN was 0.041 it 0.005 pmol/15 nin in the experinents with

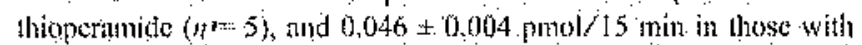
bicucultinc $(n=6)$. Histamine levels returned to basal values during wishoul of llie componds. However. ricilher thoperamide nor bienculline; infinsed into the TMN, produced any clange in the rẹlease of histamine from the dorsal straium (Fig. $3 \mathrm{~A}$ and $\mathrm{C}$ ). Histamine spontancous release from the dorsal strialum was 0.044 i 0.004 pmol/15 min in the experinents with thioperamide $(n \div 5)$; and 0.049 t 0.004 pmol/15 min in those with bienculine $(n-6)$.

\section{Effects of local perfusion of thioperamide or bicuculline} into the TMN on histamine release from the TMN and NACC

When thioperanide $(300 \mathrm{~mm}$ ) was added to the TMN-perlising medium for $60 \mathrm{~min}$, histanine redense from the TMN increased

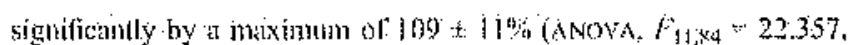
$P<0.000 \mathrm{j}$ ), bü wais nol significantly dhanged in line NAcc (Fig. $4 \mathrm{~A}$ and $B$ ). Inereased fistamitie fevels persisted during perftsion with ilioperamide, after which basal histanine levets were gutickly atained. the mean spontaneous release of histinine was $0.043 \pm 0.004 \mathrm{pmol} /$ 15 min in tirc TMN, and $0.037 \pm 0.004 \mathrm{pmol} / 15 \mathrm{~min}$ in the NAcc

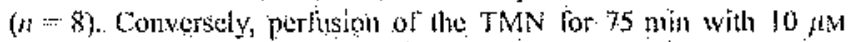
bicuctlline increased significantly the spontancous relesse of histamine not only from the TMN (ANOWA. F $15,6027.589, p<0,0001$ : Hig; 4D), but also from the NAec (ANOVA, $F_{\mathrm{b}, 60}:=13.445$, $P<0.0001$; Hig. 4C). Histerthite maximal increnses were, respeclively, 99 is $5 \%$ in the TMN and $123-2 \mathrm{~s} \%$ in the NAcc listamine oulput retumed slowly to baseline values after TMN perfision will bictacullitie was complete. Histamine spontaneous release averaged $0,044 \pm 0.003$ pnonol/15 min From the $\mathrm{TMN}$, and $0.035 \pm 0.002$ pmoly 15 min from the NAce (n -6$)$

Local perfusion of thioperamide or bicuculline into the TMN increased histamine spontaneous release from both the TMN and the prefrontal cortex

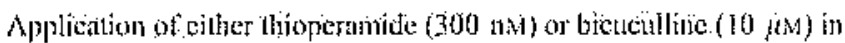
the TMN elicited a significan increase of histanine release from both the TMN (ANGVA, $F_{11,48}=8266, P<0.0001$, and $F_{11,4}=17.55$ ), $P<0.0001$, respectively) and ihe preliontal cortex (ANovi, $F_{11,48}=8.387, P<0.0001$, and $F_{11,48}=11.395, P<0.0001$, respectively). [n lite TMN, thioperamide und bictuculliie produced maximal increases of $110 \pm 13 \%$ (Fig. 5B) and $106 \mathrm{tw} 12 \%$ (Fig. 5D), respectively. The mean spontancous release of histamine from the TMN was
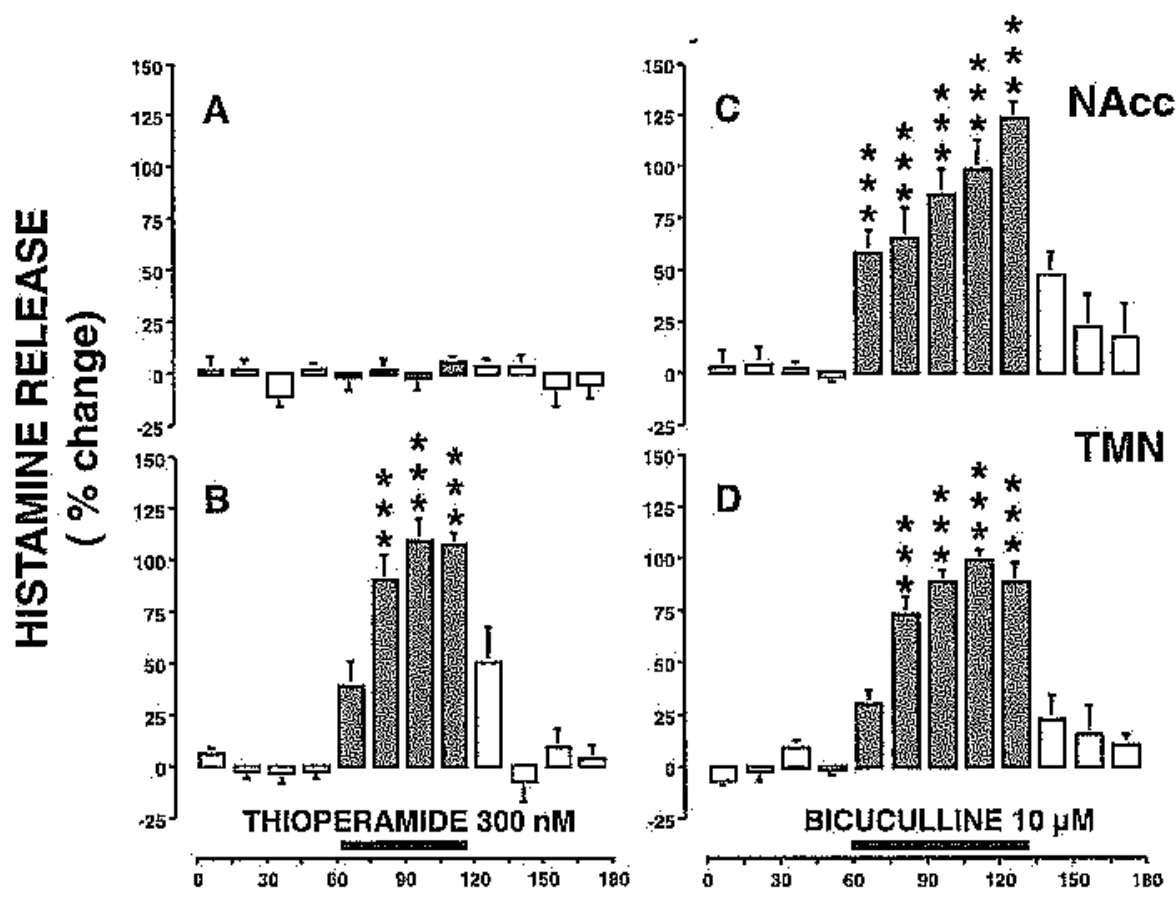

\section{TIME (min)}

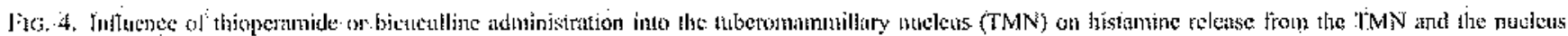

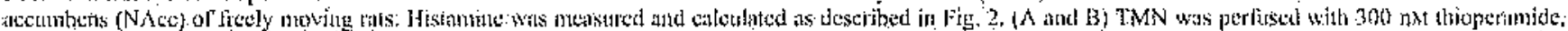

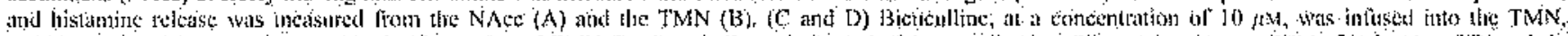

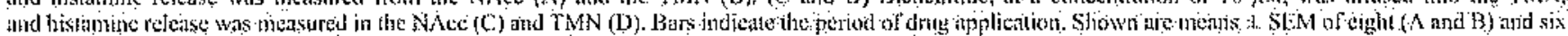

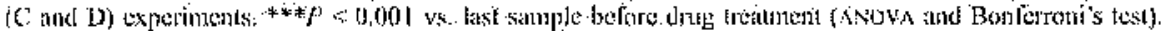




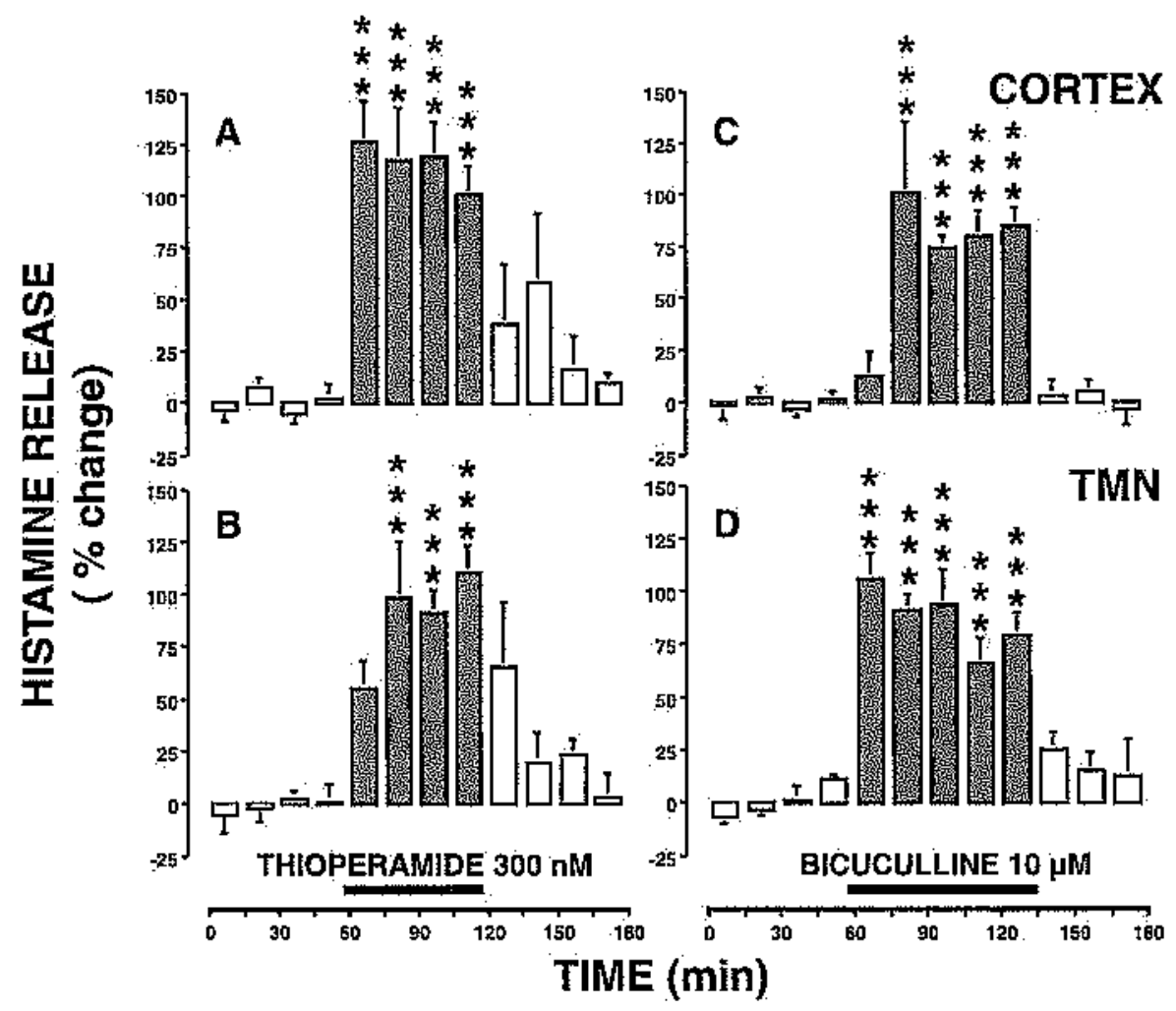

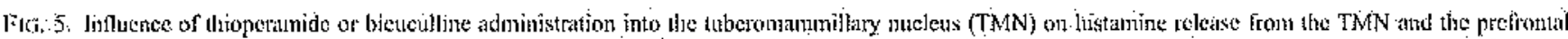

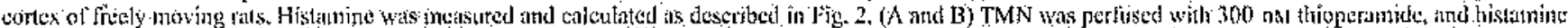

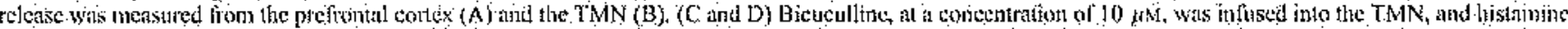

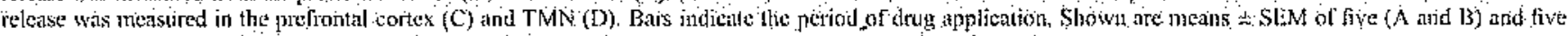

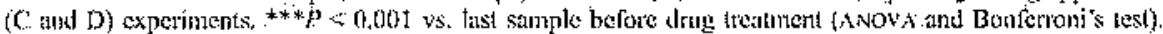

$0.042: 0.004$ provol $/ 15$ min in the experiments with thioperamide $(n=5)$, and $0.046: 0.005 \mathrm{pmol} / 15 \mathrm{~min}$ in those with bicuculine $(n=5)$. In the prefrontal cortex, thioperamide and bietculline produced maxinal increases of $136: 30 \%$ (Fig. $5 \mathrm{~A}$ ) aind $101 \pm 34 \%$ (Fig: 50 ). respectively. The mean sporilanedus release of hisitanine from the prefrontal cortex was $0,042 \pm 0.003$ pmol/ 15 min in the experiments will thioperamide $(n: 5)$ and $0.033 \pm 0.004$ pmol/ I5 min in llose with bictculline $(n: 5)$.

\section{Single-probe experiments: local perfusion with thioperamide} increased histamine spontaneous release from the NBM and the prefrontal cortex, but neither from the dorsal striatum nor the NACC

To. explore the local effects of $H_{3}-R$ blockade in the histaminergic projection areas, etich rat was implemted in the NBM, dorsal striatum, NAce or pretrontal cortex with a single probe used to simulinieonsly administer ihioperanide and monitor local clianges in histanine release. A 60 -nin applicalion of thioperantide $(300 \mathrm{nM})$ in the NBM eltciled a significant, transient increteise of histamine release (ANOYA, $\left.F_{11.108}=21.199, P<0.0001\right)$ witl] a maximal value of 130 . $10 \%$ (firg $6 \mathrm{~A}$ ) The mean spontaneous retease of histanine from the NBM was $0.050 \pm 0.005 \mathrm{pmol} / 15$ unin $(n-10)$. A similar elfeci was observed when the prefrontal cortex was perfused with thioperamide: When this drug was added to the medium perfusing the pretrontal cortex at the concentration of $300 \mathrm{nM}$ for $60 \mathrm{~min}$, hislanine sponta. neouis release increased significantly (ANOVA, Fil.24 $\div 3.962$, $P<0.0001)$, will a miximum of $87 \pm 8 \%$. The mean average spontaneous release was $0.040 \neq 0.004$ pmol/ 15 nin $(n=3$ ). Histamine spontancous relcase returned to biscline levels after perfusion wilh hioperninide was complete (Fig. $6 \mathrm{C}$ ) Conversely, pertusion of the NAce (Fig. 6B) or the dorsal slratum (Fig. 6D) Tor 60 min with $300 \mathrm{~nm}$ thioperantide had no significaly elfect on spontaneous histanine release. The clanges in spontaneous histamine relense werc always willin the range of variability (approx. 20\%) olserved between individual 15-min collettion periods during peritsion with control medium, The mean spontaneous release of histamine was $0.037 \pm 0.003$ pmol $/ 15$ min from the NAcc $(n=5)$ and 0.045 t 0.009 prol/15 min from the dorsal strintim $(n=4)$.

\section{Unilateral, local perfusion of thioperamide into the TMN} increased histamine spontaneous release from the TMN and the time spent in wakefulness of freely moving rats

Under bascline conditions ditring microdialysis experiments abou $90 \%$ of the rats were quiescent or sleeping during the entire period prior to drug treatment. To understand the profile of wake behaviout in thioperamide-trealed rats, we perlonned a sel of experiments specifically aimed at establishing the total time spent in the awake state for $2 \mathrm{~h}$, that is under bascline conditions (TMN-perfusion witli control medieni) for the first $60 \mathrm{~min}$ and during unilatera! TMNperfision witl thioperamide $(300$ aM) for the following 60 min. Sinultaneously; we determined the level of histamine release from the TMN. Luxperiments were perfomed between 10.00 and $12.00 \mathrm{~h}$ to redice the influence of circadian phases, $\Lambda$ s shown in Fig. 7 . perrusion of the TMN with $300 \mathrm{nM}$ ilhioperamiste increased signif 

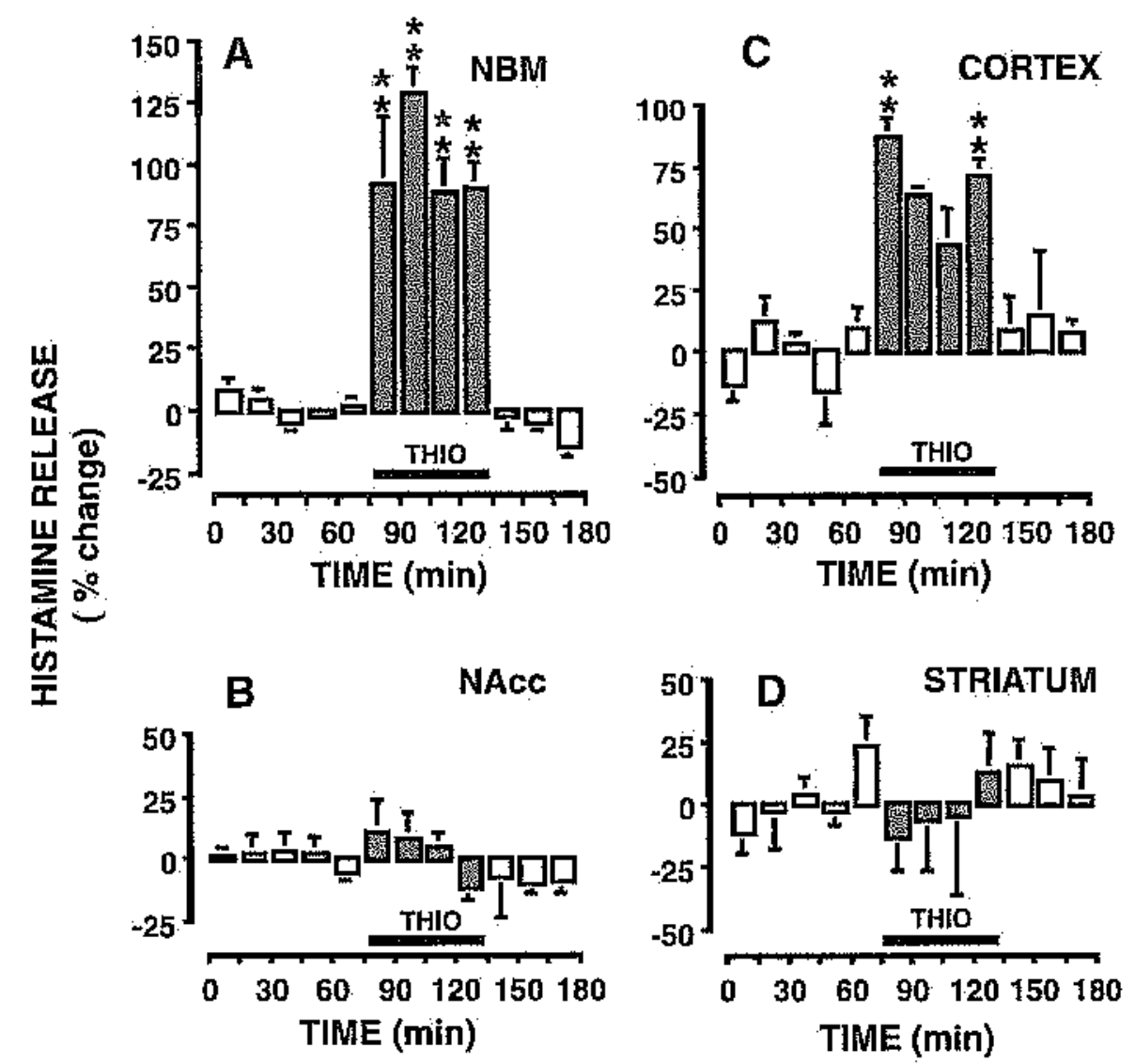

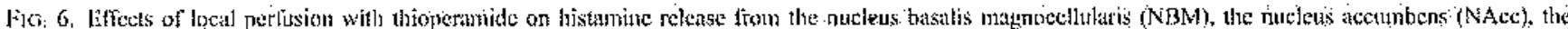

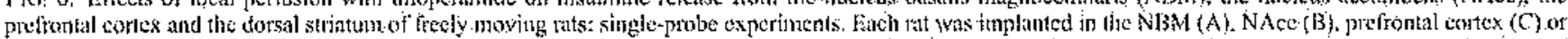

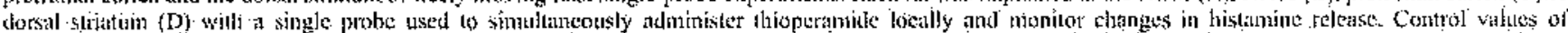

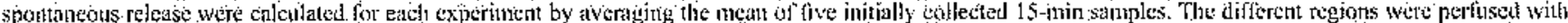

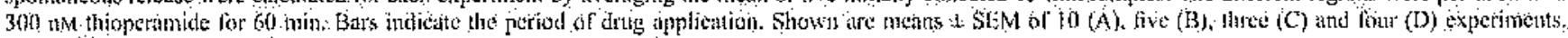

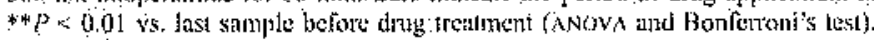

icanlly TMN histamine release from $265+31$ fimol/60 min to $530 \pm 46$ finol $/ 60$ min $(i n=7$, unpaited $f$-1est, $p<0.0005)$, aind the lime spent in wakeliuliessis from $78+20$. 10 $290+96 \mathrm{~s}(y=7$. unpaired tolest, $P<0.05$ ).

\section{$\mathrm{H}_{3}+\mathrm{R}$ immunostaining in the posterior hypothalamus}

The petterin of $\mathrm{H}_{\mathrm{s}}-\mathrm{R}$ inmenostaining in coronal sections of rat brains. was comparable to that previously reported (Chizol et $d$., 2001 :

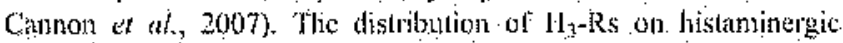
netrons in the posterior bypothalanis was examined by perfoming double-iminumofluorescence tabelling of hypolnatamies slices will a combination of anti- $\mathrm{H}_{3}-\mathrm{R}$ and anti-HDC artibodies, the latter to

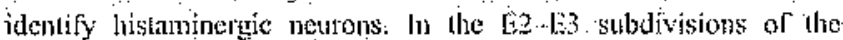
TMN, HDC-immunoteictive neurons are densely preked and $1 I_{Y}-R$ immunostaining is reatively dense, AIt HDC-posilive cells displnyed $\mathrm{H}_{\mathrm{s}} \mathrm{R}$-iminunoteactive producl $(\mathrm{Fig}, 8)$.

\section{Discussiön}

All histanineric axons originte from the TMN to innervate scycral brain regions, inctuding the hypothalatnus, NBM, NAce, siriatum and prefontal cortex (Inagaki ot at., 1988; Panula et al. 1989a). These leitures are consistent with hislanine functional influence over a host of physiological processes, such as slcep wake cycle appotíte, nociception, cognition and emolion (Browlr of al. 2001; Hats \& Pantala, 2013: Passuni of al, 2004). However, listaminergic menrons have been regarded as a single functional tuin acting as a regulaiory network for whole-brain aclivify (Wadi at al., 1991). Here wo demonstrate that responses to $\mathrm{H}_{3}-$ or $\mathrm{GABA} A_{A}-\mathrm{R}$ antagonists differenthate histaminergic neurons according to their projection areas. This is the firsi cuidence that they are organized into. functionally distinct circuits impinging on differeit brain regions, and displaying selective control mechanisns. 'The histaminergic netrons fire at at tate lizal can vary, depending on the bethavioural state; and the TM neturons are

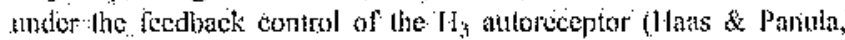
2063) $\mathrm{Ca}^{24}, \mathrm{~K}^{\mathrm{N}}$ and $\mathrm{Na}$ menbiatice conductances maintain a stable; pacemaker-like firing pattern inlrinsic to histaminergic neurons (Haas \& Reiner, to 88 ; Stevens \& llans, 1996$), 1 t_{3}-R$ s on ncuronal sonala provide a tonic intibition, as the $H_{3}-\mathrm{R}$ antagonist thioperamide

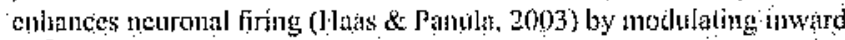
Ca currents (Reinet, 1987; Sievens at at, 2001). Ho $\mathrm{H}_{3} \mathrm{ks}$ are also present on presynaptic terminals (varicosities) of histaminergic axois.

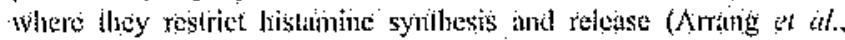
1983. 1985). Therefore, blockade of somatic and presynaplic I $\mathrm{l}_{3}$-autoreceplors converge in augnenting histanine levels in the synaptic deft. 


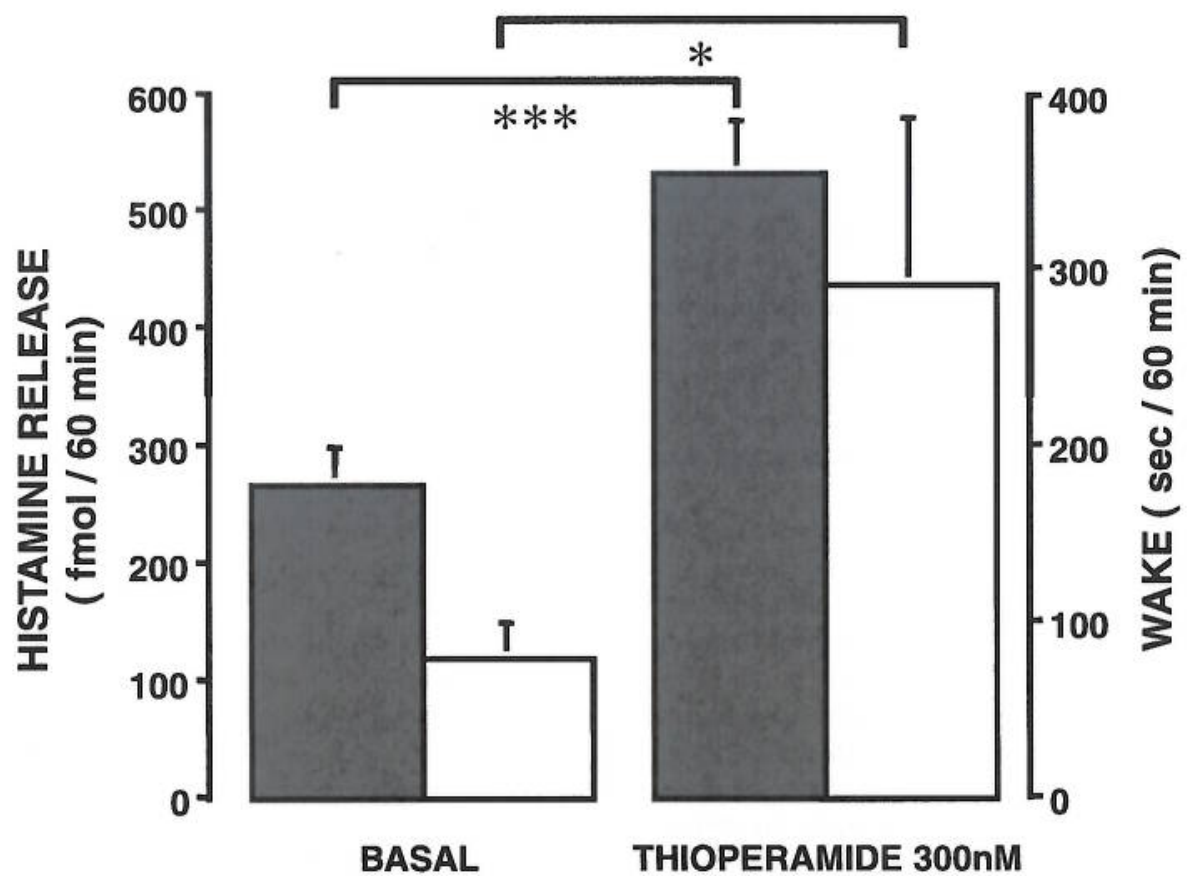

FIG. 7. Influence of thioperamide administration into the TMN on histamine release from the TMN and time spent in wakefulness. Experiments were performed between 10.00 and $12.00 \mathrm{~h}$. Histamine levels were measured in the absence and presence of thioperamide. Rats, implanted with a single probe in the TMN, were initially perfused with control medium for $60 \mathrm{~min}$ (basal), then with a medium containing thioperamide ( $300 \mathrm{nM})$ for an additional $60 \mathrm{~min}$. Simultaneously, the waking time of each animal was measured by experienced individuals, blind to the experimental protocol. Shown are means \pm SEM of seven rats. ${ }^{*} P<0.05$ $* * * P<0.001$ (unpaired $t$-test).
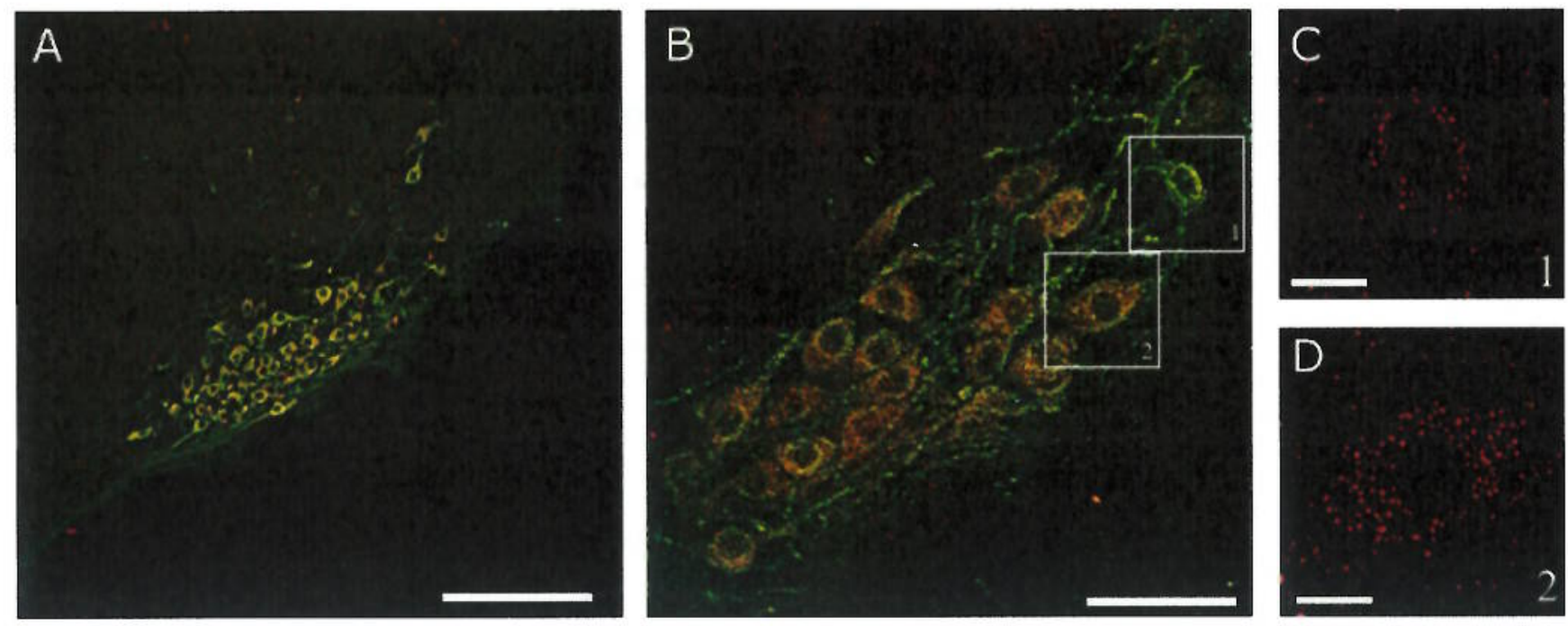

FIG. 8. Distribution of $\mathrm{H}_{3}-\mathrm{R}$ on TMN histaminergic neurons. (A and B) HDC-positive cells in the E2-E3 subdivision of the TMN showing $\mathrm{H}_{3}-\mathrm{R}$ fluorescence; (C and D) high-resolution z-projections of $\mathrm{H}_{3}-\mathrm{R}$ expression in the HDC-positive neurons selected in (B). Observations were repeated in three rats with similar results. Calibration bars: $160 \mu \mathrm{m}(\mathrm{A}) ; 40 \mu \mathrm{m}(\mathrm{B}) ; 8 \mu \mathrm{m}$ (C and D).

Double-probe microdialysis in freely moving animals provides a powerful means for defining the dynamics regulating histamine release in discrete brain regions. TMN histamine is probably released from short projections that form extensive axonal arborizations in the posterior hypothalamus. Because in the present study thioperamide was applied locally to the TMN, histamine increase was the 
consequence of blocking botly somalic and presynapic tratitoreceptors, attluengh the participation of only one component canriot be exchited.

Following hioperanida alministration ino line TMN, histamine feleasc was significantly increased in the Ni3M and prefrontal cortex. 'This was likely due to dischatge potentiation of histamine netrons sendirg alferejts to these regions. Analogonsly, stimulation of the TMN with prostaglandin- $\mathrm{F}_{2}$ (lluang et al., 2ot3), orcxiin $A$ (Ilitung et al, 200i) or endocannabinoids (Cermi et al, 2006) incteased histanine release from discrete brain regions, as a mesult of histaminetgic projection activation. The NBM and cortex reccive a very abundant histaninergic innervation (Panula et $a$, 1989b), and display both high $\mathrm{H}_{3}-\mathrm{k}$ binding and gene transeripls (Pillol ef al, 2002). Accordingly, single-probe microdialysis experiments showed that admintstration ol thicperanide in the NBM or prefronal cortcx angnented significanily histumine relcasc within these regions, an effect that can be explained by blockade of local II-atitoreceptors.

It is generally tssumed ilat all histaminergic neutons express $H_{3}-R s$; and response: to $H_{3}-R$ ligands is a criferion for their identification in wime. Supprisingly, during T'MN perfistion with thibperamide histamine levels rentained stabte in the dorsal stritum and NAce, despile the fact that these brain arens receive histaninergic innervation (Panula et al. 1989b), Under the sanie experimental

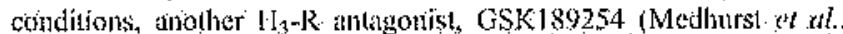
2007). filly mimicked thioperantide actions (Giamoni $t a t$, 2007). Our tesnlts indicale that histamine netrons projecting to the siriatum and NAce are insensitive to thioperamide. Altiough the perlision site was elose to the ventral, and far from the dorsal and rơstral TMN, spatial segregation due to probe locilization does not explain the lack of response. In lact, relrograde lacing with alye injections into the sirtatum or prefrontal cortex showed that most histaminergio somata are within the medial part of the ventrol TMN (Kohler of al., 1985). This proximity suggests that hisianinergic somata projecting to the strialum and prefrontal cortex had llie same exposure to lhioperamide bul werc not affected in the same way. Morcover, biencilline adminisiered inlo the TMN atigniented significantly hislaninc release from the NAce. Under the same experimental eonditions; TMN pertusion will cannabinoid receptor I agonists increased listanine rclease from the dorsal striatum (Cenni at al, 2006). Noticeably, also the local perfistion of the striatum or NAce with thioperanide did not modify histanine release; this indicating that the whole somatoderdritic domain of hislaminergic netrons projecting to these regions is insensitive to $\mathrm{ll}_{\mathrm{y}} \mathrm{R}$ antagonists, Accordingly, lesion experiments indicale that the vast majority ol $\mathrm{H}_{3}$-Rs in the NAce and striatum are not associated with histaminergic fibrẹs (Cumming of $a l_{x}$ 199. Pollard ot al, j993), which is consistent will high dessities of mRNAs levels in the sanc regions (Chazol ot al, $200 \mathrm{~L}$ : Pillot of ats 2002 Cannon $a t a l, 2007$ ), suggesting a postsynaptte localization of thése receptors.

Several $\mathrm{H}_{3}+\mathrm{R}$ isolorms have becn described, including 6-4ransmembrane-domain isoforms lacking functional response to $\mathrm{H}_{3}$ - $R$ ligands in recombinant cells (Bakker et ah, 2006). All HDC positive cell bódies exlibited $H_{y}-\mathrm{R}$ umniznoreactivity, but llwe antibodies avaltable do not discriminate between isolorms (Clazol et al., 2001): Hence, in vivo insensilivity to dhioperamide may depeind on lifgh expression of particular isolorms.

GABAergic inpuls from the ventrolateral preptic nucleus innerwate histaminergic neurons (Fricson, 1991: Sherith et al., 1998). $G \wedge B \wedge_{\Lambda}-\mathrm{R}$. activation inhlbits directly histaminergic cells frithg rate (Yang \& Hatom, 1997; Stevens at ah, 1999), whereas intilition increases significantly TMN histamine reiease (Cenni at at, 2006), in the present study, bicuenline is incfective of 'TMN neurous projecting to the NBM, as shown previously (Cenne ef al, 2006), and stratum. Conversely, TMN pertusion will bicuculline signifiearity increased bistamine releatse from the NAce and prefontat cortex. These differences are consislent with previous findings. Finctional hetcrogencity of CABAcrgic symaptic potentials atrong histaminergic neurons was found following stimulation of the diagonal band of Broca, antero-lateral hypothalanus or lateral preoptic area (Yang \& Hatton, 1997), histanmergic nenrons display different degrees of $G A B A$ serisitivities depending on $G A B A_{A}-R$ stbunil expressions (Sergevat $e t a, 2002,2005$ ), The novel finding here is that sensitivily to bicucutline relatcs to TMiN netrons lieterogencity witl? resped to projuction fiekss.

Unilateral, ittra-TMN admitistration of thioperamide elicited a significant inerease of TMN histamine release, but only a moderatc, although simpificunt, waking eflect. Thioperamide increased relense of histanine from the prefromal contex and NBM, wo brain regions with prominent rotes in histamine waking action (Cha ot al., 2004; Ranesh at al, 2(004). However, a recent report showed that only a relatively low level of cumulative tyake activity for thioperantide was linearly correlated with the to $80 \%$ of the receptor occupancy (Le $\mathrm{ot} \mathrm{al,} \mathrm{2008).}$ In contrasi, an abrup break from linearily and a robust inerease of waking activity was observed at doses that produce greater ban $80 \%$ oceupancy (Le at $a l, 2008$ ). Otr resutis suggest a relatively small increase of waking activity ithat maty be cotisistent will the low level of teceptor oecopancy achievablic with unilateral administration of the drug.

In conclusion, the present data suggest that listaminergic neurons are not aniforn; and that they establisli linetionally dislitict pathways according to their terminal projections, that are sensitive to selective pharnacological manipulations, and rebetcd to independent fintions. Firther sudies are required to understand the full implications of such

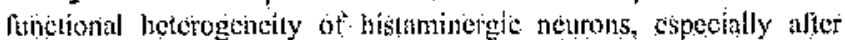
systemic altministration of $\cdot H_{3}-R$ antagonists, given their potential for trealing a number of iniportant human diseases (Estrenshade at $a l_{\text {, }}$ $2008)$.

\section{Acknowledgements}

This rescarch was sulponted by Universita di Firenze lunds, PRIN 20077

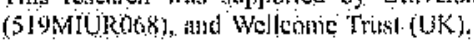

\section{Abbreviations}

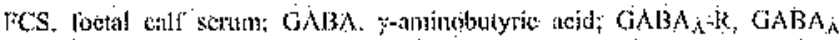

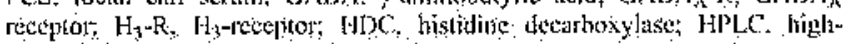
performatice líquid chromatomariy . NAce, nucleus accuinbers; NBM, moleus

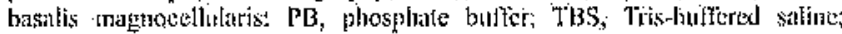
TMN, tubermmanntinilary muesei.

\section{References}

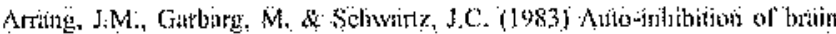

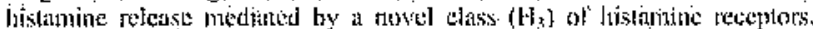
Nithute. 302, 832-837

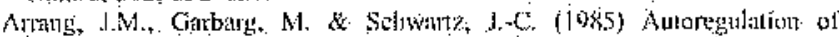

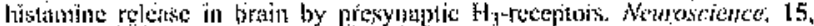
$553 \cdots 562$.

Arang: f.M., Garbare. M. Lancelot, IC. Lecoml. JiM.: Pollaxa, H., Roblu

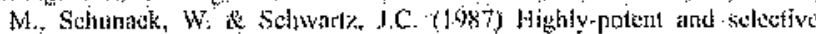

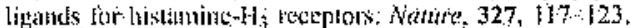

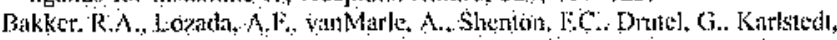

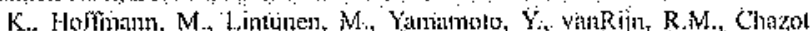

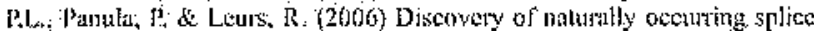




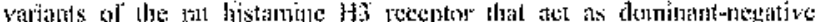

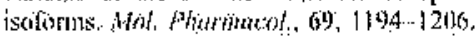

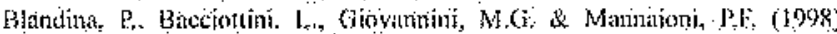

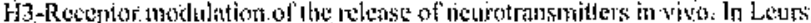

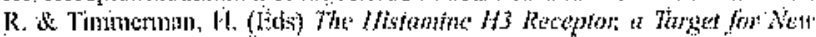
Drigs. Elsevier, Artusterdans, pp. 27.40.

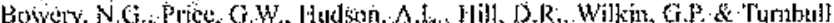

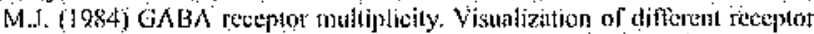
ypes in the mammalian CNS, Netrowhomerologe: 23, 219.23!.

Brown. R.R., Stevens, D.R. \& Haas, H.L. (2001) The physiulogy of brain

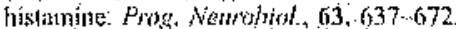

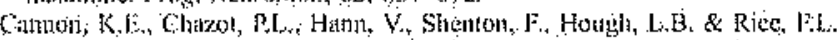

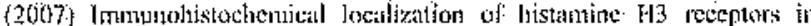
rodenl skju, dorsal root ganglia, superion cervical ganglin: and spinal cort: poltitial antinocicentive tatgets. Paim, $129,76 \%$ ?

Genni. G. Blandina, P., Mackic. K. Nosi, 1). Tornigli, L. Giannoni, P., Bailini,

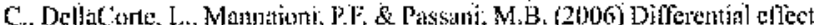

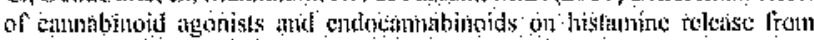

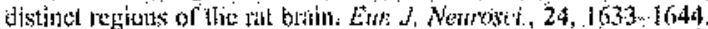

Chazot, P.L., Hainn, V. Wilsom, C. Lees, G. \& Thompsoo, C.L. (2001) limmunologicil identificition of the mammitian $\mathrm{H}_{3}$ bistamine recestot in the inouse brait. Newrocert, 12,259262

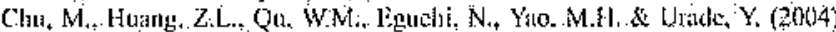
Iixtracelludar histamine level in the frontal cortex is positionaly conclated with the amoun of wakefuluess in rats, Nousosci. Res, 49, 417-420.

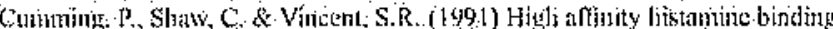

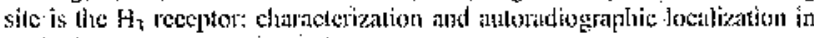

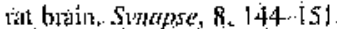

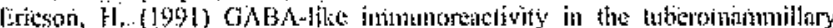

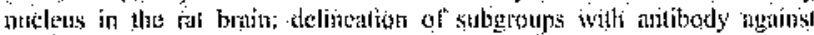
L-histidine decarboxitase as a marker, $j$ Comp. Neurel. 305. 462.469

[Erieson, H., Waituabe, T. \& Köliler, C. (19S7) Morpho]ogital analysis of the

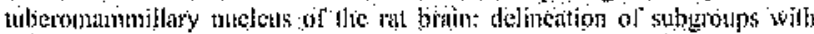

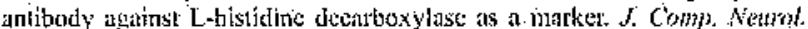
$263,1 \cdots 24$

Esbensiade, 'T.A., Browmia, K.F., Biner. R.S., Straklovi, M., Cowat, M.D. \& Brion, J.D, (2008) Thic histamine $\mathrm{H} 3$ recepton an attractive larget for the

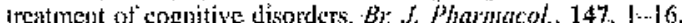

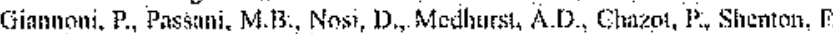

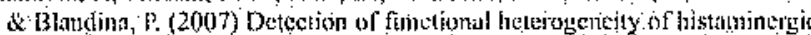
neurols in responise to GSK 189254, a novel H3 receptor antatonist. dXXF

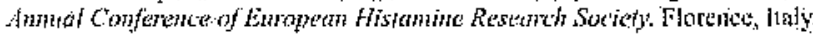
Ifi p.

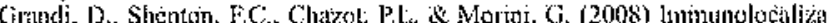
tol) of histamine 113 reteptoms on endocrinc cells in the rat gasisotntestinat Iract. Hisiol Hotopathot ; 23, 789-798.

Hasis. H. \& Janula, P. (2003) The role ol histannine and the tuberomatmillaty

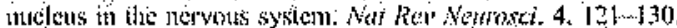

Hass, H.L. \& Riner, P.B. (1988) Membrane properties: of histaminergic

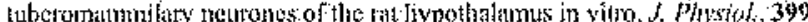
633.646 .

Hais, H., Serged vil, O. \& Sclhach, O. (2008) Histamine in the nervous system Phisiol tien: $88,1183 \ldots 1241$.

Fiaxlui, MA. Totentino-Silva, F, Pece, G., Kc, P. \& Mack S.O. (200) Montiaminergic netrons, elbemosensation and arotisal. Respir Physiet. 129, $191 \cdots 209$.

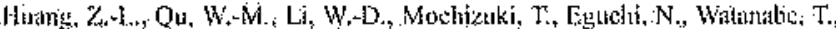

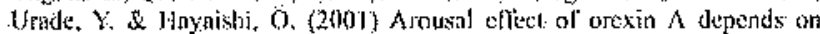
activalton of the bistaminergic system. Proc vatl Acad Sct.98, 9965 9970.

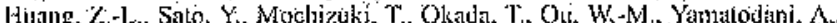
Urade, Y, \& Hayaisli, (O) (2003) Inositulandin F2 Activates the Histimin-

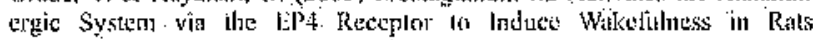
J. Neinsed, $23,5975 \ldots 59$.

Inagati. N: Yamalodani, A. Ando-Yaniontoto, M, Tohyanta, M., Watanabe, T

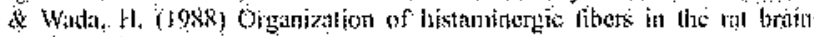
J. Comp. Neurd, 273, 283300

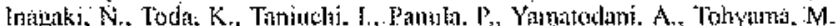
Watanabe, T. \& Wadr, H. (1990) An dinlysis of histangineresic efferents of

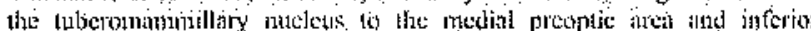
colliculus of the rat. Exp. Brom Res $80.374 \% 380$.

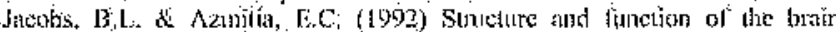
scrotonits system. Phytol. Ret, 72, $165: 229$

Ko, E.M. Estabrooke. J.V, McCarthy, M \& Scameli, T,E (2003) Wake related activity of iuberchmenuitillaty netrons in rats. Brain $R e x, 992,220$ 226 .

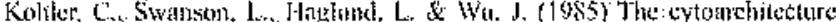

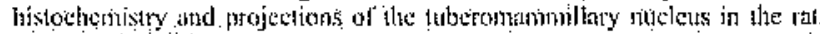
Nerimosiance, $16,85 \% 110$

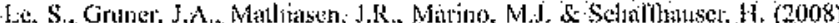
Correthtion between ex rivo receptor ocelpansy and wake-promenting

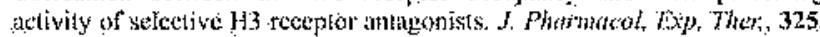
902.909

Matson; S.T. \& Fibiger, H:C, (1979) Regjond topograply withit notidrenergic boess coetuleus as reveiled by retrograde transport of horseradish peroxithise d, Comp. Netiolt, 187, 703 $\cdots 724$

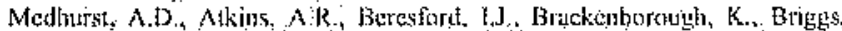

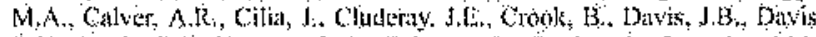
R.K., Davis, R.P. Dawson. L.A., boloy, A.C., Garilon i., Gonzaler Mit Heslop. T. Hirst, W.D. Jituriags, C., Jomes, D,N., Lacrix, L. P., Martylt. A.

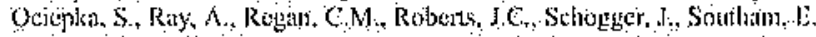
Stean. T.O. Titil. B.K. Ifpten, N., Wadsworlt. G., Wald, J,A., White, T. Witheringion, J. Woolley. M.L. Worby, A \& Wilson; D.M. (2007)

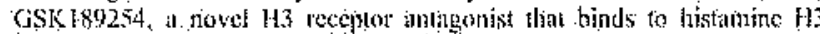

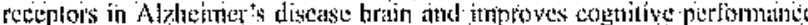
in preclinical models. $I$. phomocol Exp ther, $321,1032 \ldots 1045$.

Miklos, I.H, \& Kowales. K, J. (2013) Junctional heterogencily of the retgonses

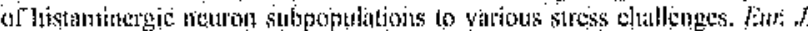
Namoste 13,3069 3679.

Morisset, S., Rouleat. A, Lignean, X, Gbahon, F. Tardivel-Litconthe, I.

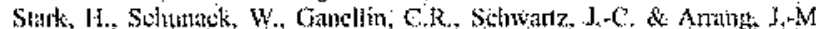

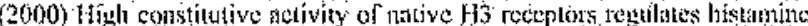

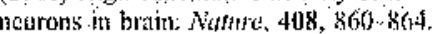

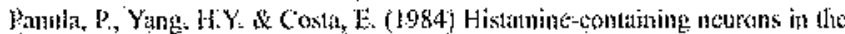

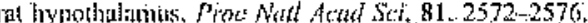

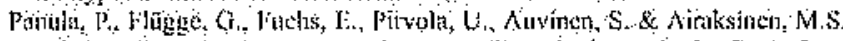

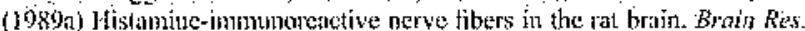
484. $234-236$

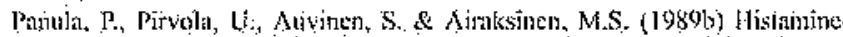

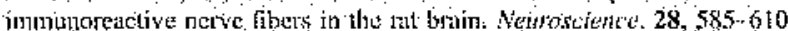

Passumi, M.B. Lin, J -S., Hancock, A. Crochet, S \& Blamdilak, P. (2004). The thislamine $\mathrm{H} 3$ receptor as a novet thempentic target for tognilive and sleep ilisolders. Thents Pharmacol Sct, 25. 618.625.

Paxinos, G: \& Watson. C. (1998) The Rat Brom in Stereotuxit Condinater. Agadeuic Press, New York.

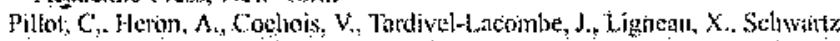

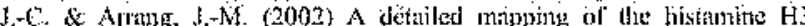

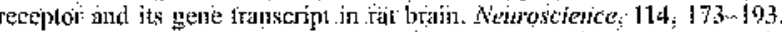

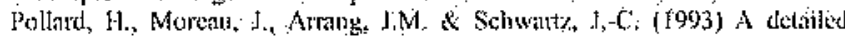
attoradiographic mapping of histamine Jis receptors in fal bratn areas. ventrositence, $52,169 \ldots 189$

Ramesh, V., Thakkat, M.M. Streckes, R.E., Basiser, R. \& Mcharley R.W. (2004) Wakefilness-julucine cfiects of histantine in the basal furebraits of frecly moving tais. Behat Brom Res., $152,271 \cdots 278$

Réner, P.B. (1987) Electroplys busicical propertics of contically projecting

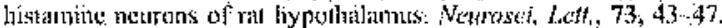

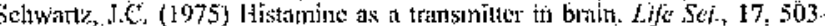
517:

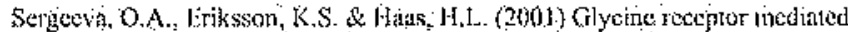
responses in rat histaninergic neurons. Newosci, Lett 3010, 5 ..

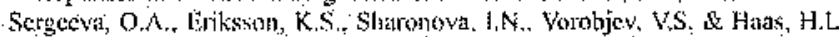

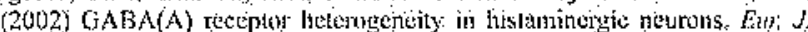

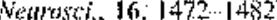

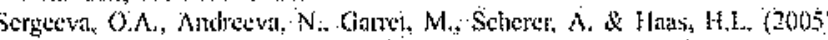

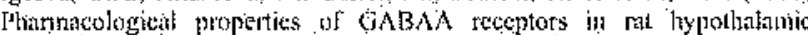

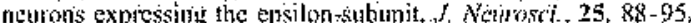

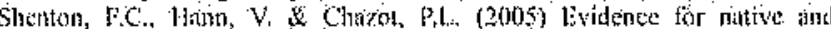

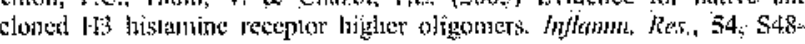
$\$ 49$

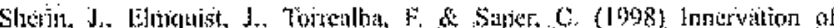
utbermmmilary neuroms by Gabatrge and gatanimergic netrons in the

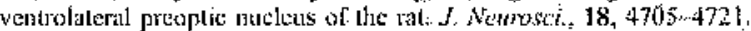

Stevens, D.R. \& Hals. H.L. (1996) Galcitm-(ependent potentials contribute to

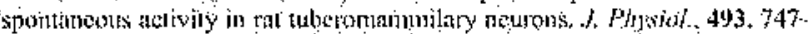
754 .

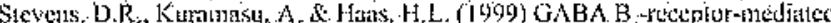

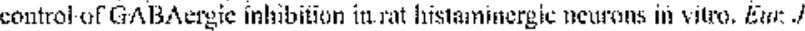
Netirastic. II, $1148 \cdots 1154$.

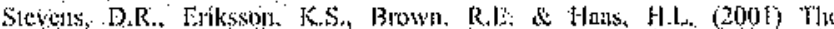

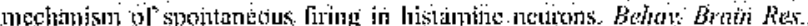
124, $165 \ldots 112$. 


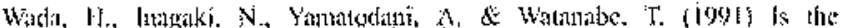

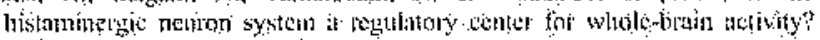

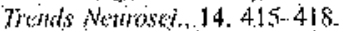

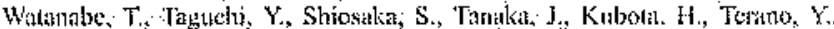

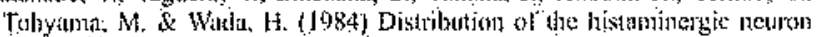

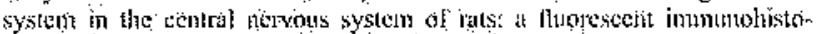
clicinical analysix with histidine dectrboxy fisce as al inarker. Brom Rets. 295. 1325

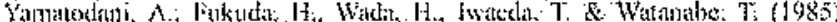

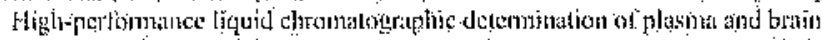

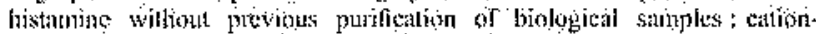

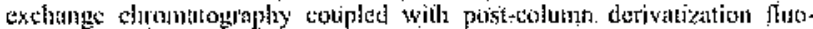
romelry, f. Chromatogr, 344, $115 \% 123$.

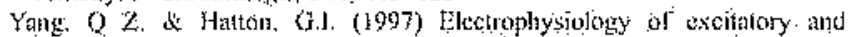
inlibitory afferents io ral histeminergic tuberomammillary nuclets nicurös

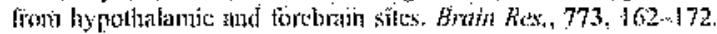

